\title{
緊張性アテトーセ型脳性麻㾝の一患者を対象とした描画支援システムの開発*
}

\section{Development of Drawing Assist System for One Patient with Tension Athetosis Type Cerebral Palsy} \\ Tomoyuki NAKAO, Hiroaki AOYAMA , Ken'ichi YANO*1 , \\ Naruto MIYAGAWA , Naoki KUBOTA and Satoshi HORIHATA \\ ${ }^{* 1}$ Department of Mechanical Engineering , Mie University \\ 1577 Kurimamachiya-cho, Tsu City, Mie, 514-8507, Japan
}

中尾 智幸 $* 1$, 青山 寛明 $* 2$, 矢野 賢一 $* 1$, 宮川 成門 $* 3$, 窪田 直樹 $* 3$, 堀畑 伀 $* 4$

Creative activities, such as painting and music, are one source of satisfaction and fulfillment for people with disabilities. However, some individuals with disabilities cannot satisfactorily enjoy such activities due to involuntary movement. In this study, we developed a drawing assist system for patients with cerebral palsy of the tension athetosis type, who experience involuntary movement. It has been difficult for the assist system to distinguish involuntary movement from voluntary movement. We designed a variable filter to attenuate involuntary movement on the basis of characteristics of synthesized velocity with respect to involuntary movement. Our system enabled drawing based on the participant's own senses and motor control, even when experiencing involuntary movement.

Key Words : Human-Machine Interface, Cerebral Palsy, Involuntary Motion, Moving Average Method, Drawing Assistance, Pointing Device, Blurring Compensation

1. は じめ に

身体障がいを持つ方の中には, 自己表現の手段として樣々な創作活動を行っている方が多い . 創作活動の一つ に絵画があり，身体障がいを持つ方は残存機能を活かして絵を描いている．たとえば，上腕の機能か制限されて いるならば，手先を巧みに動かし，上肢全体の機能が制限されているならば，口や足を上肢機能の代替として活 用することにより絵の描画を行っている ${ }^{(1)}$. 近年はパソコン機能や福祉用具の発展により，身体障がいを持つ方々 にもコンピュータグラフィックを活用した創作活動が広まってきた．しかしながら，彼らが創作活動を満足に行え るかどうかは障がいの程度に依存しており，不随意運動を伴い自分の意志通りに身体を動かせない場合には，細 かく正確な動作が困難となり絵を描きたくても描くことができない.

これらの問題に対し，入力デバイスからポインタ描画までの処理に関して，不随意運動の影響を除去するシス

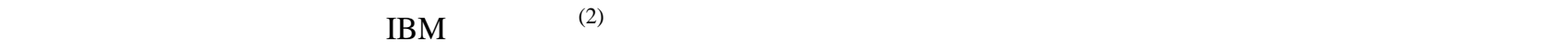
カスタム設計するプログラムを可能な限り活用することを考慮に入れていたが , このソリューションはあまり現実 的ではないと述べている . 光の理由は, 不随意運動が一樣でなく気まぐれに変化するため, セットアップしても時 間の経過に伴い, 有効でなくなり頻繁な再調整が必要となるからと述べている.結果的に, 1 次のローパスフィル タのカットオフ周波数をダイヤルを回すことで調整するという簡素な仕組みを用いて Assistive Mouse Adapter を

* 原稿受付 2010 年 10 月 24 日

*1 正員, 三重大学大学院工学研究科機械工学専攻 (广 514-8507 三重県津市栗真町屋町 1577)

*2 岐阜大学大学院工学研究科人間情報システム工学専攻 (广 501-1193 岐阜県岐阜市柳戶 1-1)

*3 岐阜県生活技術研究所試験研究部 (广 506-0058 岐阜県高山市山田町 1154)

$* 4$ 正員, 日本大学松戶歯学部数理科学教室 (广 271-8587 千葉県松戶市栄町西 2-870-1)

E-mail: yanolab@robot.mach.mie-u.ac.jp 
開発している.

一方で森本らは, 不随意運動による影響をリアルタイムに減衰させるペイントッールを開発した ${ }^{(3)}$. 手振れの減 衰手法には，移動平均法による平滑化だけでなく，大きな振れへの対策手法として切り替え補正手法と強制補正 手法を提案している．切り替え補正手法は，閾値を超えた移動量に対して移動平均個数を大幅に増加させる手法 である．強制補正手法は，平均的な描画方向を直線の基準軸と設定し，基準軸からの距離が大きい入力座標を強 制的に基準軸上へ移動させる手法である．また，白石らはペンタブレットでの入力において移動平均法の補正点 と終端入力点との間隔にさらに移動平均法を用いて線画を滑らかにする手法を提案した ${ }^{(4)}$. しかしながら従来手法

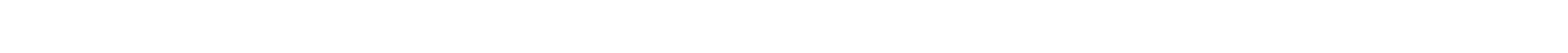
強い不随意運動を持つ方の場合は，入力デバイスの平面保持の困難さ，振えの非周期性，強弱の不規則さのため， 产の効果を発揮できない.さらに, 大きな動作の不随意運動の頻度が高くなるため, 通常の移動平均法ではサン プル数を常に多くする必要があり，操作性が悪く意図通りの描画は困難となる．以上のことより，非周期的な強い 不随意運動に適応しつつ，操作性のよい描画支援システムの実現か望まれる．

そこで本研究では,リアルタイムに不随意運動の状態に適した補正を実現する可変型フィルタリング技術を開 発し，非周期的な強い不随意運動を有しても絵の描画を可能とする描画支援システムを開発することを目的とす る. 本論文の最後には, 非周期的な強い不随意運動を持つ緊張性アテトーゼ型脳性麻瘏者を対象として実際に描 画テストを行い, 非制御時および通常の移動平均法と比較することにより，不随意運動の影響に対する可変型フィ ルタの減衰性能を示すとともに，本提案手法の直感的操作性を示す．

\section{2. 脳性麻痺患者を対象とした描画支援システム}

不随意運動を伴う病状では脳性麻瘦が代表的である . 脳性麻瘏は出生前から新生児期 (生後 28 日) の間に生じた 脳障がいによって引き起こされる運動機能障害を指す症候群である ${ }^{(5)}$. 筋緊張に動摇性がみられる場合をアテトー セ型 (athetosis) という. 随意運動時や精神的動摇により筋緊張は動摇し，持続した姿勢保持が困難となる．随意運 動を行おうとすると運動量をコントロールしたり停止できず過剩な運動が起こる(6). 特に緊張性アテトーセ型脳性 麻瘦の不随意運動は, 帯の急激さが特徵であり, 精神的な緊張で不随意運動が著しく悪化する . 不随意運動は姿 勢あるいは運動を持続しようとするときに現れ，姿勢保持中は筋緊張が六進し，休止状態では筋緊張が低下する (7).また，本国における脳性麻瘏に代表される脳原性全身性運動機能障害の患者人口は 6 万人を上回る ${ }^{(8)(9)}$.

本研究では緊張性アテトーゼ型脳性麻瘏の方 1 名に被験者として協力いただいた . 被験者は体を動か乥うとす ると強く速い不随意運動が発生し，さらには精神的な緊張で不随意運動が悪化する. 光のため，ほとんどの生活 動作が困難であり全介助を受けている .一方で自助具の利用や環境の工夫により，パソコンのキーボード操作の み自力で行うことができ，絵や短歌などの創作活動を行っている．パソコン使用時は，不随意運動を最小限に抑 えるため被験者自身で左上腕を肘置きと胴体の間に挟み込むと同時に右上肢で左肘部を抑えこみながら，比較的 自由か効く薬指と小指を用いて操作している . 操作時に左上肢の肘から先しか使えず可動範囲が狭いことを補う ため，キーボードには左右にスライドする台とミスタッチ防止用のプラスチック製キーガードが取り付けられて いる.ポインタの操作はキーボードのテンキーにマウス機能を割り当てることにより行われる .キーボードを操 作する際にみられる不随意運動は，左右方向・上下方向・手前奥方向のいずれにも不規則かつ予測不可能であり， 捻る動作や反る動作も複合される．また，手首関節・肘関節・肩関節を中心とした不随意運動だけでなく体幹が 動摇する不随意運動もあり，これらが複合し複雑な動作として不随意運動があらわれる．

被験者の普段の描画方法は，写真から輪郭を抽出し，乥の輪郭内を塗りつぶすという簡素な方法にとどまって いる．弚のため，実際に紙面に描画するような絵をパソコンで描きたいという要望を持っているが, 現状の自助 具や環境の工夫だけでは困難である．また対象とするような重度の不随意運動を有する方への入力デバイスとし ては, 平面保持が必要なマウスやペンタブレットは適さず, 3 次元的に動作可能かつ 3 次元座標を計測可能なデバ イスが必要となる .さらには, ペンタブレットのペンを落としてしまうなど, 不随意運動の影響で操作部から手 を離してしまったときに, 自力で拾うことは非常に困難であるという問題がある .

本研究における実験環境は図 1 に示されるように , 入力デバイスを使用者の正面に使用者の姿勢に合わせて約 $10[\mathrm{deg}]$ の傾斜をつけて設置し , ディスプレイを正面に使用者の見やすい高さて設置した . 入力デバイスには上記の点 
を考慮し , 小型ハプテイックインターフェースである PHANToM Omni(SensAble 社製) ${ }^{(10)}$ を用いた .PHANToM Omni は 3 自由度のアームとスタイラスカ接続された 3 自由度のジンバルで構成される 6 自由度デバイスである.アームの 各軸にエンコーダか設けられており，第 4 軸から第 6 軸の回転軸が交差する点であるジンバルの回転中心点の 3 次元 座標を計測することが可能である.ジンバルの回転中心点 $P$ を描画のための入力点として用いた . ここで入力デバイ スを基準とする入力座標系 $\Sigma_{P}\left(x_{P}, y_{P}, z_{P}\right)$ を, 使用者に対して左右方向を $\mathrm{x}$ 軸, 前後方向を $\mathrm{y}$ 軸, 上下方向を $\mathrm{z}$ 軸と して設定した . 机上て絵を描くときや字を書くときと同樣な感覚で作業できるように , 入力座標系 $\Sigma_{P}$ における描画 面は $x_{P} y_{P}$ 平面と設定した . 入力デバイスの設置条件により， $x_{P} y_{P}$ 平面は水平面に対して傾斜している.PHANToM Omni には土台の正面側にキャリブレーション用の穴が設けられており，スタイラスの先端を挿入することで初期 座標を得る . キャリブレーション時の入力点 $P$ の初期座標は, $P(0)=\left(x_{P 0}, y_{P 0}, z_{P 0}\right)=(0.000,0.088,-0.065)[\mathrm{m}]$ である . 図 1 左下の入力デバイスの図において, 入力点 $P$ を示し, 各矢印は $P$ に関する各軸の正方向を示す . 2 次 元であるディスプレイ上の描画座標系 $\Sigma_{D}\left(x_{D}, y_{D}\right)$ は画面左下を原点とし設定した . $x_{P}$ と $x_{D}, y_{P}$ と $y_{D}$ の正の方向 は光れ光れ等しく対応している．

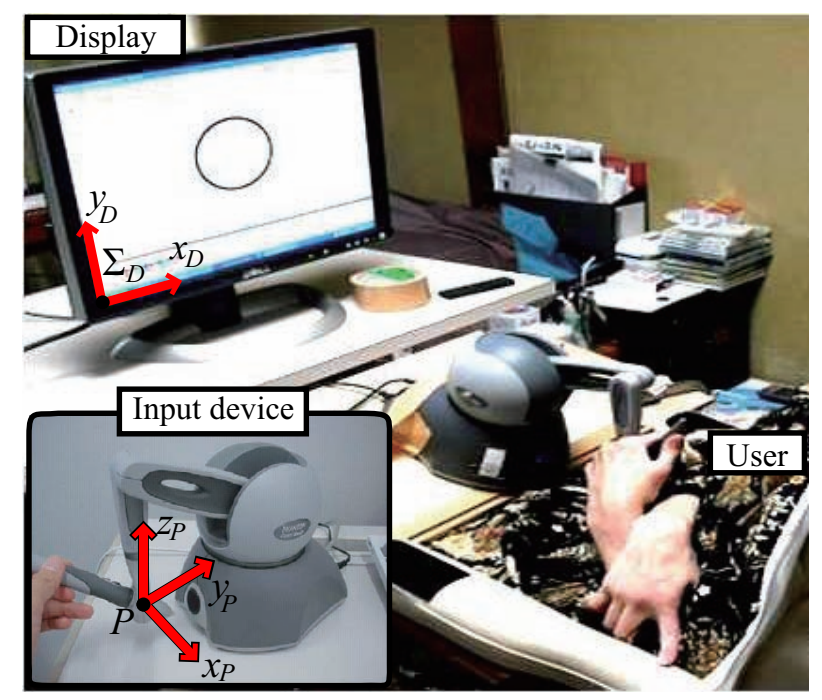

Fig. 1 Experimental setup for drawing assistance system

\section{3. 不随意運動解析}

不随意運動による影響を減衰させる可変フィルタを設計するための予備実験として, 被験者による入力デバイ スの操作テストを行った . 具体的には, 被験者にディスプレイ上で $0.08[\mathrm{~m}](280$ ピクセル)の円の内側にポインタ

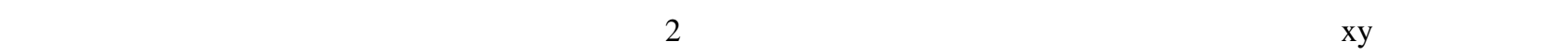
けるポインタの 2 秒間の位置変化である .

結果より，一連の操作動作中に図中 (a) に示すような恒常的な弱い不随意運動と，図中 (b) に示すような突発的 な強い不随意運動が混在していることがわかった .この強い不随意運動が発生した際は随意を全く反映できなく なるほど操作が非常に困難となる．

次に, 特徵的な周波数帯域を調べるために各軸方向におけるスペクトル解析を行った．弚の解析結果を図 3 に 示す . 図中 (a) には弱い不随意運動のスペクトル , 図中 (b) には強い不随意運動のスペクトルを示す .

不随意運動の強弱を比較すると，パワーが高いのは共に低周波数帯域である．日常生活動作の随意運動は主に， 低周波帯域の動作であり，不随意運動の高パワー成分と同帯域に存在する．弚のため, 単に通常のノッチフィルタ を用いた減衰手法を適用すると，随意運動まで除去してしまい，利用者の動作意志の抽出が困難となる . 次に各 軸のパワーバランスに着目すると, $\mathrm{x}$ 軸方向のパワーが優位に高くなっているように見える．しかし，アテトーゼ 


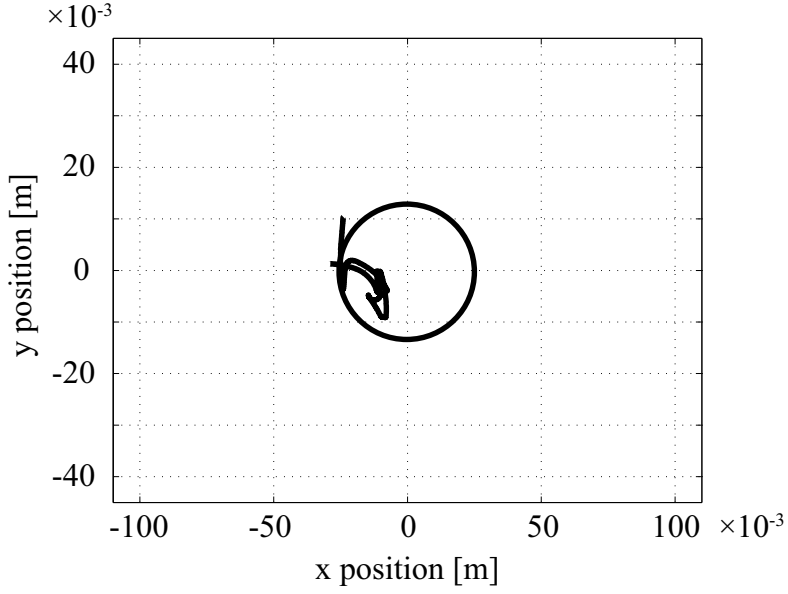

(a) Weak involontary motion

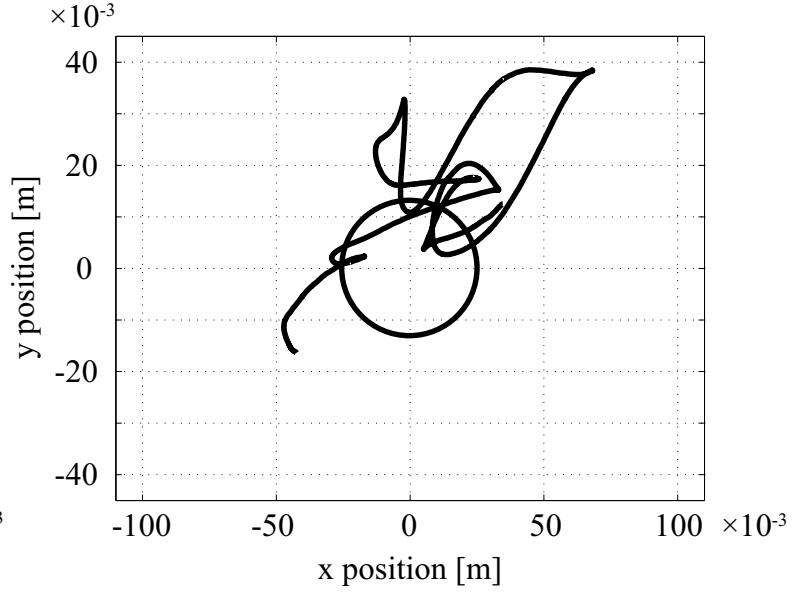

(b) Strong involontary motion

Fig. 2 Involuntary motion on X-Y coordinate plane

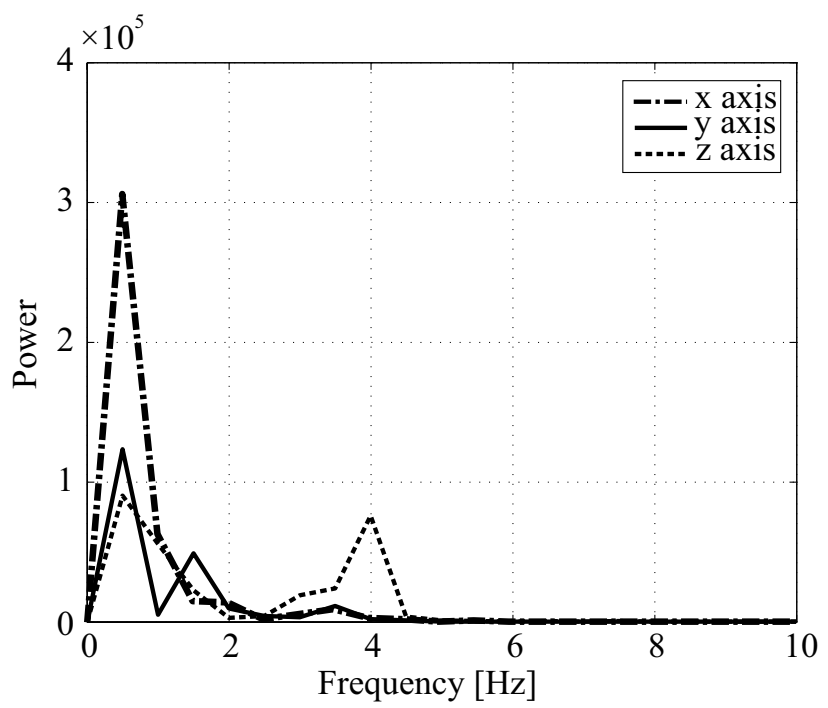

(a) Spectrum of weak involuntary motion

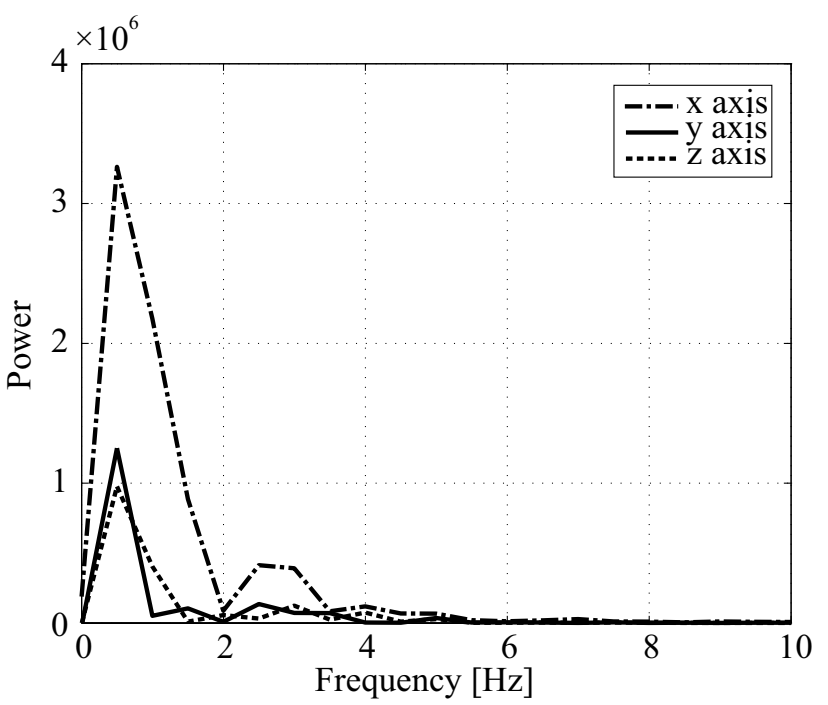

(b) Spectrum of strong involuntary motion

Fig. 3 Spectrum of involuntary motion

型の不随意運動は，第二章にて述べた強弱があり方向および移動距離が不規則かつ複雑であるという特徵に加え， どんな随意運動をしようとしているのか, 弚のときの姿勢や骨格構造など樣々な要因が絡み複雑な運動となるた め，解析に用いる不随意運動のデータによってパワーバランスが異なる．仮に，ある方向のみ特殊なフィルタを かけた場合は，光の特殊さにより他のアテトーゼ型脳性麻疸患者に適さないものになると予測できる . 以上のこ とからスペクトル解析における各軸のパワーバランスから不随意運動の特徵を見出すことは有効でないと考えた .

次に速度変化に着目し，指標として各軸の合成速度を用いた解析を行った . 本研究で用いた合成速度の算出式 を式(1)に示す．

$$
v_{3 d}=\sqrt{v_{x}^{2}+v_{y}^{2}+v_{z}^{2}}
$$

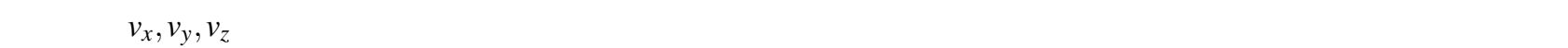
図 4 に示す. 図中 (a) は弱い不随意運動の結果を示し, 図中 (b) は強い不随意運動の結果を示す. 


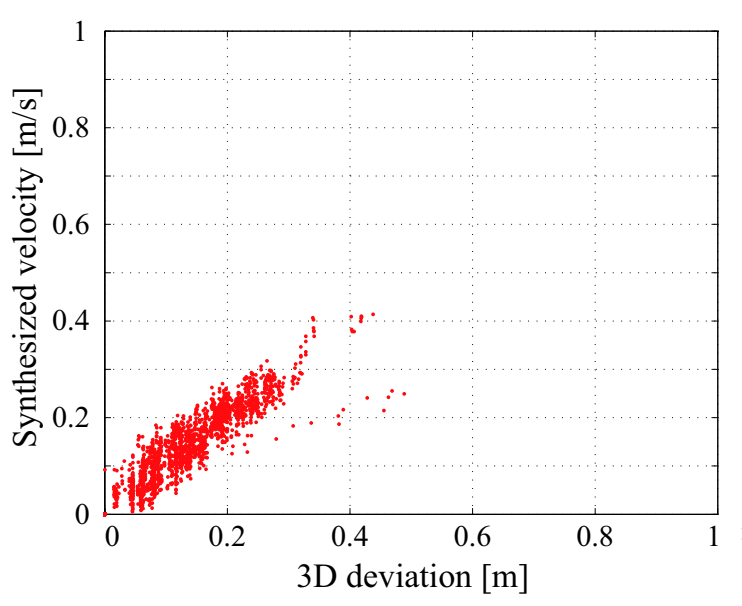

(a) Weak involuntary motion

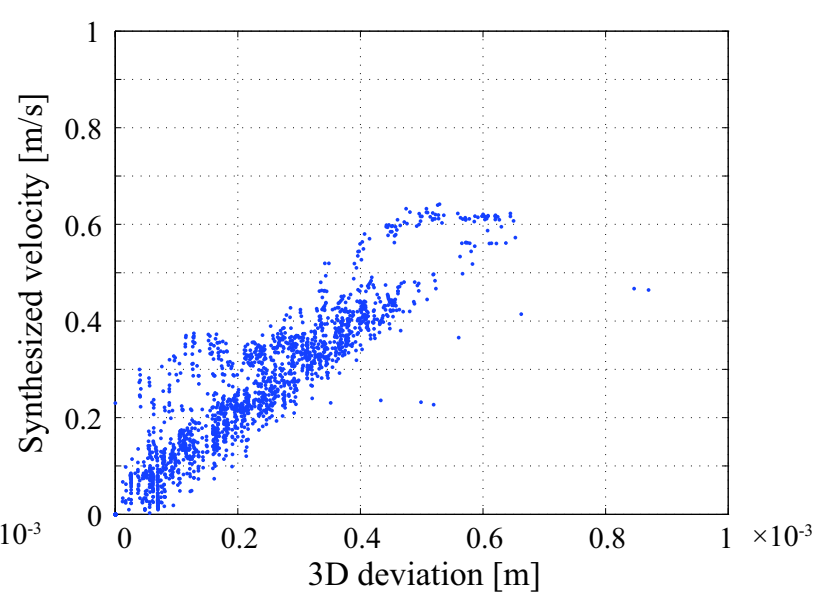

(b) Strong involuntary motion

Fig. 4 Relation between deviation and velocity

弱い不随意運動に関しては, 最大速度を含む高い速度域は $0.3 \sim 0.4[\mathrm{~m} / \mathrm{s}]$ に出現し，0.2[m/s] 前後の速度域の動 作が頻繁であることがわかる．また強い不随意運動に関しては，最大速度を含む高い速度域は $0.6 〜 0.65[\mathrm{~m} / \mathrm{s}]$ に出 現し，0.35〜0.45[m/s] の速度域の動作が頻繁であることがわかる．

結果として，移動量が大きいほど合成速度が大きくなり，さらに移動量と合成速度には線形の関係があること がわかった，これらのことから，不随意運動の強弱を区別する指標として合成速度を使用できると考えられる．

\section{4. 可変型フィルタの設計}

解析結果から, 合成速度の変化に応じて移動平均法の減衰量を変化させるフィルタを設計する.合成速度によ る減衰量の重み係数 $w_{(i)}$ は, 式 (2) に示すように設計した $\cdot i=1,2,3, \cdots$ はある時刻におけるサンプリング番号で ある .

$$
w_{(i)}=\frac{\alpha T^{n}}{T^{n}+v_{3 d(i)}^{n}}
$$

サンプル $i$ における補正点座標 $G_{(i)}=\left(x_{G(i)}, y_{G(i)}, z_{G(i)}\right)$ は, 式 (3) に示すように移動平均を応用し, 1 サンプル 前の補正点座標 $G_{(i-1)}$ と過去一定区間の入力点 $P_{(k)}$ の計測値との変化量に重み付けをすることで算出される . 次 式は $\mathrm{x}, \mathrm{y}, \mathrm{z}$ の成分毎に処理される .

$$
G_{(i)}=\frac{1}{N S} \sum_{k=i-N S}^{i}\left[G_{(i-1)}+w_{(k)}\left(P_{(k)}-G_{(i-1)}\right)\right]
$$

ここで, 移動平均時間 $N$ は $2.0[\mathrm{~s}]$, 重みの最大係数 $\alpha=1.0$, 次数 $n=3$ と設定した .サンプリンク数 $S$ は $7500[$ 回 $/ \mathrm{s}]$ である $w_{(i)}=0.5$ とするカットオフ速度 $T$ は, 弱い不随意運動の合成速度において, 最大速度を含む高い速度域 が $0.3[\mathrm{~m} / \mathrm{s}]$ 以上であるため， $0.3[\mathrm{~m} / \mathrm{s}]$ に設定した . また，合成速度に対する重み係数の変化を図 5 に示す.弱い 不随意運動に相当する合成速度が小さいとき $w_{(i)}$ は 1 に近づき, 式 (3) は単純移動平均法に近い減衰量で位置補正 を行なう．また，強い不随意運動である合成速度が大きいとき $w_{(i)}$ は 0 に近づき，式 (3) は大きな減衰量て位置補 正を行なう．このように合成速度の变化に応じてリアルタイムに減衰量を变化させる位置補正が可能となる．

以上の結果を用いて, 入力座標系 $\Sigma_{P}$ における補正点座標 $G_{(i)}$ を式 (4) によりディスプレイ上の描画座標系 $\Sigma_{D}$ におけるポインタの位置座標 $P_{D}=\left(x_{D}, y_{D}\right)$ に変換する .ここで, $L_{P}=\left[L_{P x} L_{P y}\right]$ は使用者の入力デバイスにおける 可動域のサイズであり， $L_{D}=\left[L_{D x} L_{D y}\right]$ は対応するディスプレイ上の表示領域のサイズである . 次式は $\mathrm{x}, \mathrm{y}$ の成 分毎に処理される.

$$
P_{D(i)}=\left(G_{(i)}+\frac{L_{P}}{2}\right) \times \frac{L_{D}}{L_{P}}
$$




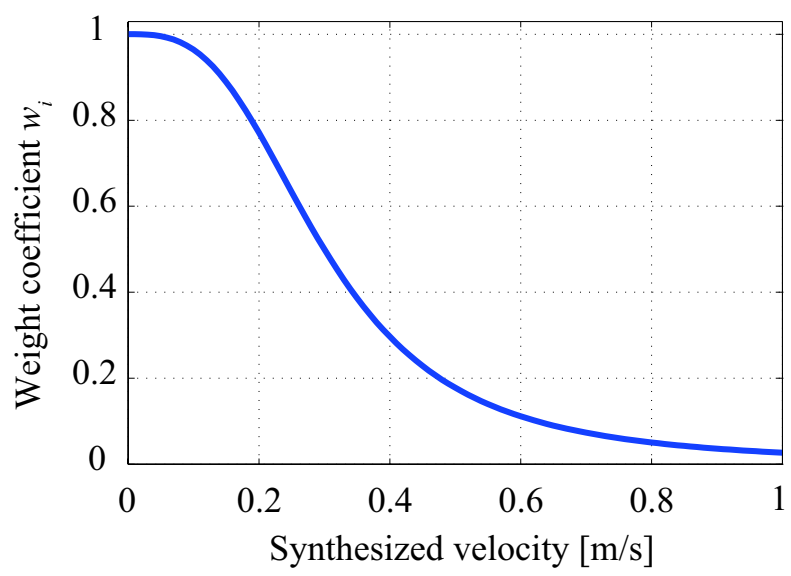

Fig. 5 Change of weight coefficient with respect to velocity

設計した可变型フィルタを不随意運動の計測データに適用し，光の有効性を検証した．まず移動平均時間 $N$ の 変化と減衰効果の関係を確認するための実験を行なった . 不随意運動解析における実験と同樣に, 円の内側にポ

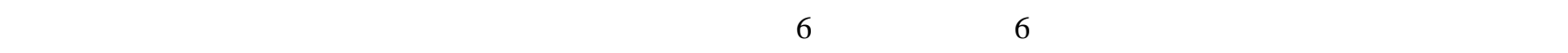
間を変化させてフィルタリングした際の結果である .
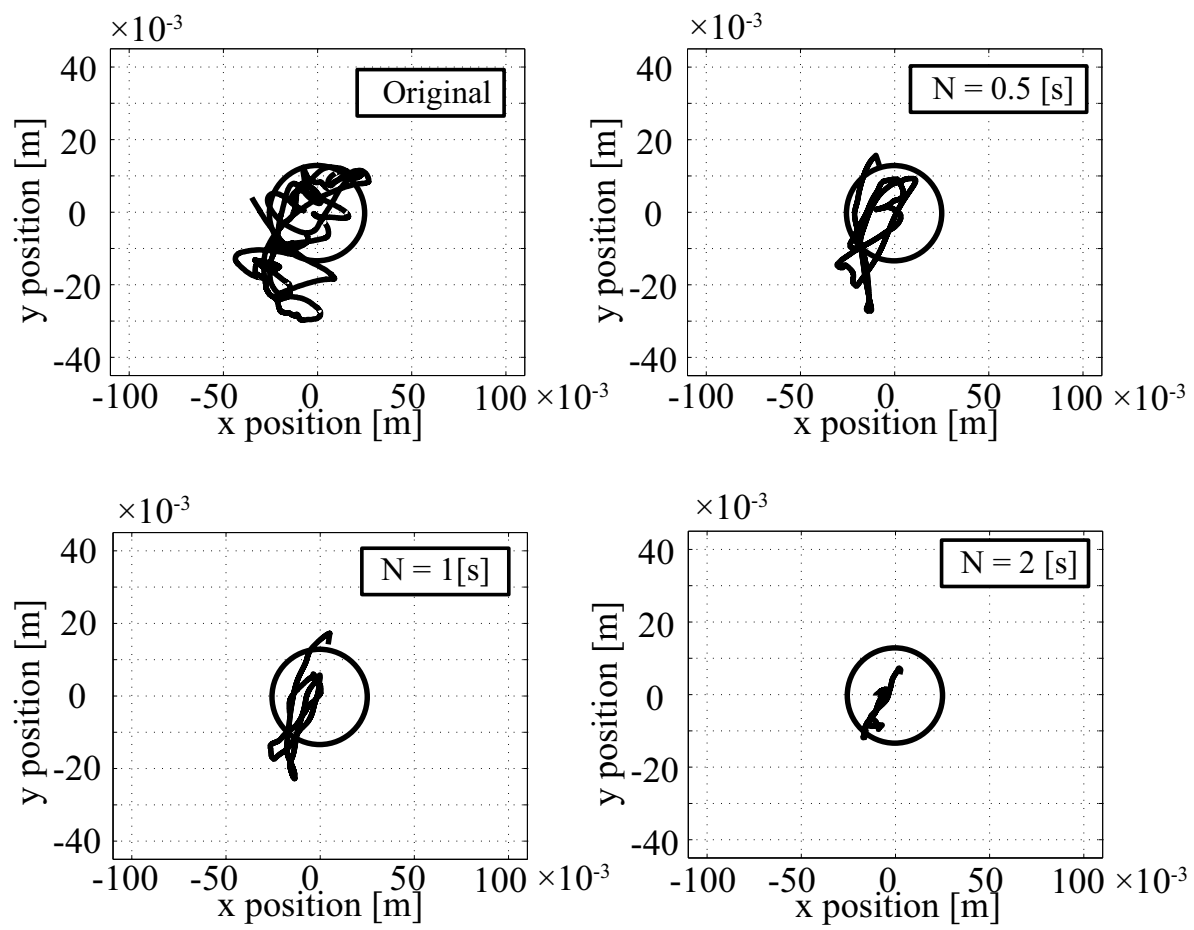

Fig. 6 Attenuation of the effects of involuntary movements for various moving-average periods

この結果における基準円に対する逸脱度と標本分散について表 1 に示すようにまとめた . 逸脱度は各座標の原 点からの距離と基準円との関係を示したもので, 基準円上にあるとき $100[\%]$ と定義した . 逸脱度に関して表中に 平均値, 最大值, 最小值, $100[\%]$ を越えたサンプル数の全サンプル数に対する割合を示す . 標本分散は各座標の 原点からの距離に関するばらつきである .これらの結果から $N$ の増加に伴い逸脱度と標本分散が減少しているこ とが分かる．また， $N=1[\mathrm{~s}]$ の結果と比較した場合でも， $N=2[\mathrm{~s}]$ の結果は逸脱度の平均值，最大值，100[\%]を 越えたサンプル数の全サンプル数に対する割合および標本分散のいずれにおいても著しく減少していることが明 
Table 1 Degree of deviation and dispersion for various moving-average periods

\begin{tabular}{|c|c|c|c|c|c|}
\hline$N$ [s] & Mean [\%] & Max [\%] & Min [\%] & Rate [\%] & Dispersion \\
\hline 0 & 113.67 & 231.14 & 6.67 & 53.59 & 55.32 \\
\hline 0.5 & 99.74 & 216.56 & 4.12 & 44.17 & 55.22 \\
\hline 1 & 88.86 & 183.61 & 2.19 & 36.93 & 45.58 \\
\hline 2 & 64.04 & 114.34 & 14.28 & 11.25 & 12.77 \\
\hline
\end{tabular}

らかである .一方で移動平均時間 $N$ を大きくするにつれ遅延も大きくなり，操作性が悪くなるというトレードオ フの問題がある . 移動平均時間が $N=2.0[\mathrm{~s}]$ 以上の場合では遅延の増加により操作性が悪化したことと，図 6 と表 1 に示すように $\mathrm{N}=2.0[\mathrm{~s}]$ において著しい減衰性能を確認したため移動平均時間 $\mathrm{N}$ は $2.0[\mathrm{~s}]$ を用いた .

次に，右下から反時計回りに一回りする動作をしてもらつた際の，xy 座標平面における原信号を図 7(a)に，移 動平均および合成速度による重み付けした軌道を图 7(b) に示す．結果より，移動平均を用いた軌道は不随意運動 による影響を減衰していることが確認できるが, 原点周辺において反発するような軌道を描いており, 強い不随 意運動の影響を減衰しきれていないことがわかる.これに比べ, 可変型フィルタを用いた軌道は, 強い不随意運 動の影響を良好に減衰できていることがわかる．

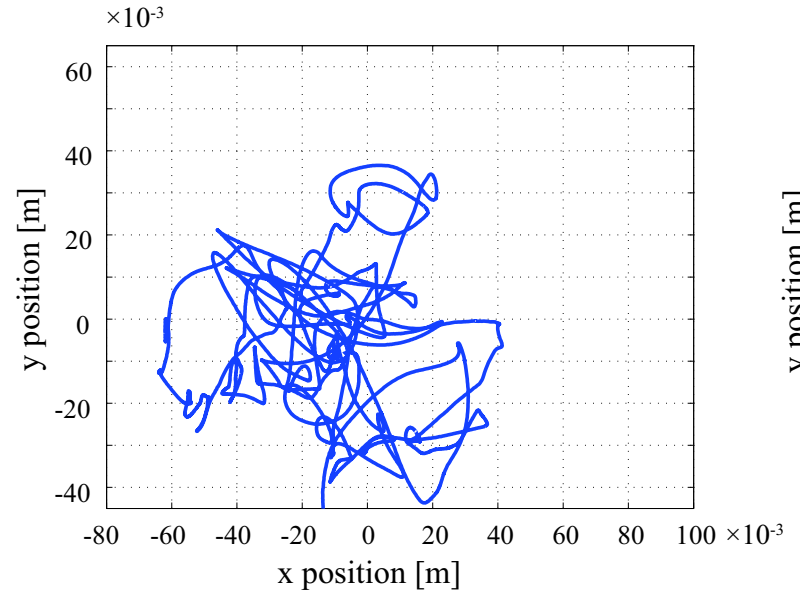

(a) Original signal

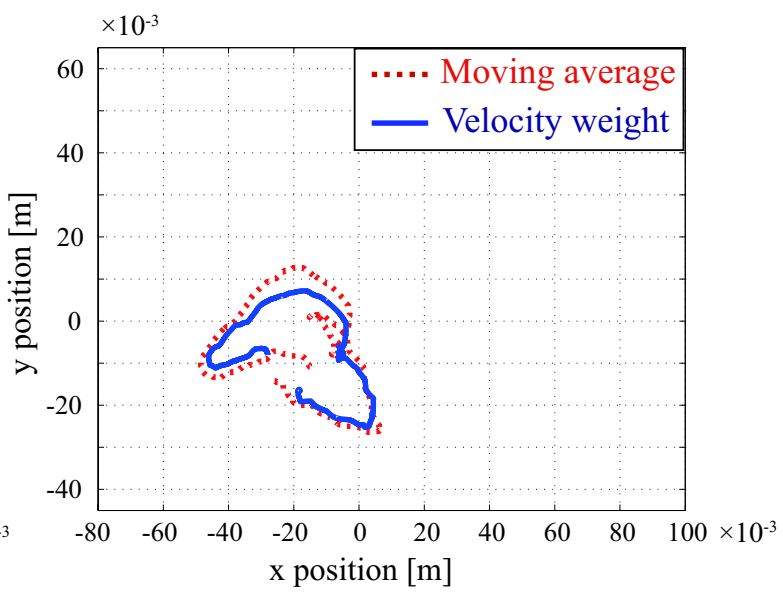

(b) Filtered signal

Fig. 7 Comparison of correction effect using method of moving average with weight coefficient

\section{5. 描画支援実験}

\section{1 描画条件の設定}

緊張性アテトーゼ脳性麻痺者を対象した場合，精神的な緊張で不随意運動か強まってしまう．つまり，何か特定 の動作を指定し，動作するように依頼すると，弚の緊張により過度に不随意運動が強くなり，上手く操作できな くなる. 光こで本研究では, 使用者が描画するイメージで動かしやすいように自由に上腕を動かしてもらい, 光 の特徵を分析・抽出することで描画手法を決定することを考える．

設定する描画条件は，ディスプレイ上の「キャンバス」のサイズと「塗り始め」の判断である.被験者は入力 デバイスを操作する左上腕の可動範囲に制限があるため, 被験者が描きやすいキャンバスのサイズを設定する必 要がある .また，使用者が思い通りのタイミングで直感的に塗り始めることを描画開始可能とする塗り始め条件 を決定するために, 塗り始めの動作と不随意運動との特徵の違いを明らかにする必要がある . この描画条件を設 定するための実験を行った . 実験方法は, 4 分割された長方形状の枠を表示し，外枠の中にキャンバスをイメージ し, 各内枠内にキャンバスの四隅を塗るイメージ動作を依頼した . 過度な指示による精神的な緊張を避けるため に, 塗り始めの動作など細かい動作の指定は行わなかった . 塗る順番は「右下」から「左下」まで反時計回りで 
ある.被験者自身が上手く操作でき塗ることができたと感じた時に「はい」と発言していただいた「右下」から 「左下」までのひと回りを 1 試行とし，これを計 6 回試行した . xy 座標平面における挙動に着目し，位置変化の計 測結果を図 8 に示す.
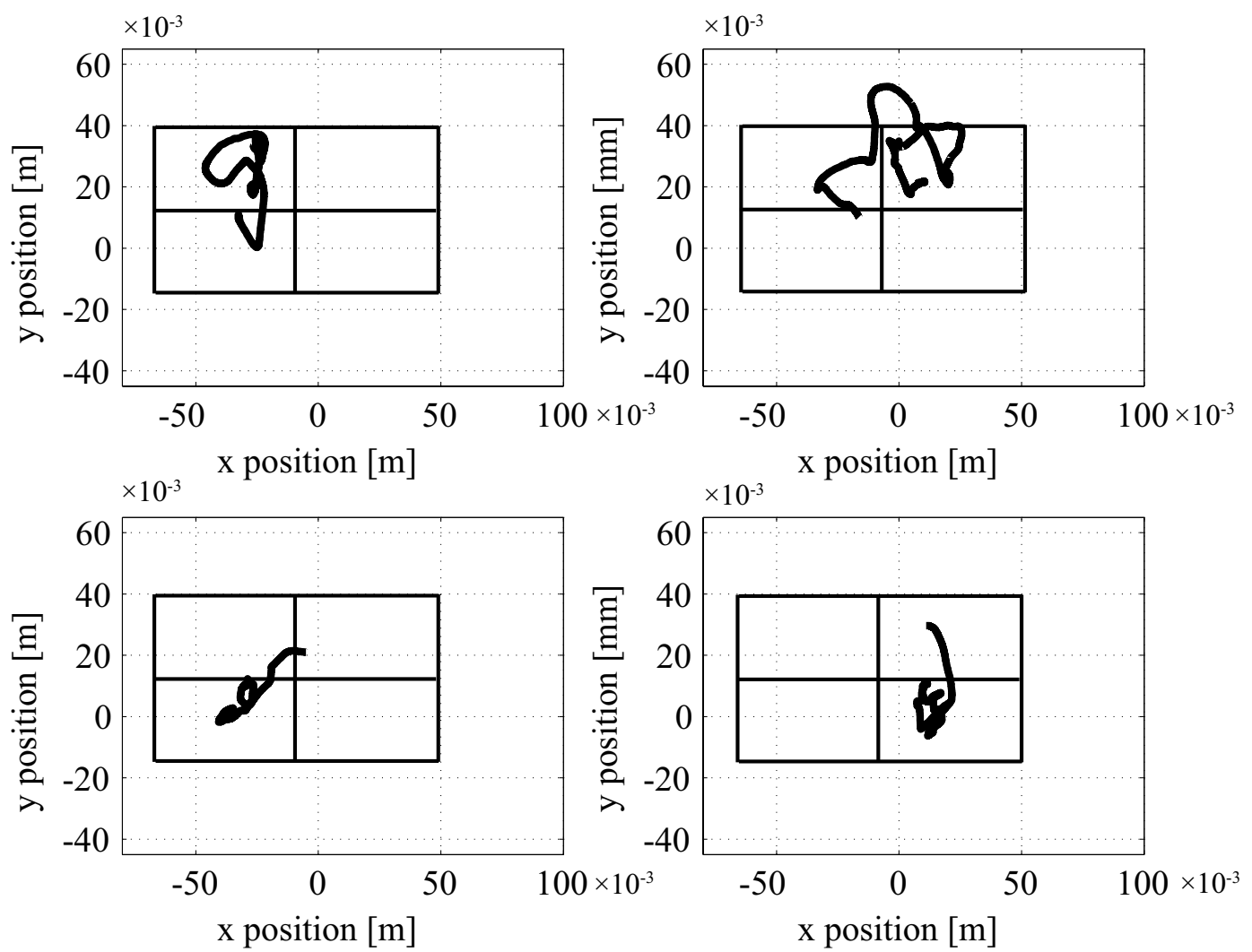

Fig. 8 Drawing motion on X-Y coordinate

結果として, 6 試行とも精度よくキャンバスの四隅を指定することができたため，この結果をもとにキャンバス の座標系と入力デバイスの座標系の対応を表 2 に示すように設定した .

Table 2 Scaling relationship between input coordinate and drawing position

\begin{tabular}{|c|c|c|c|}
\hline & Unit & Min & Max \\
\hline$L_{P x}$ & $\mathrm{~m}$ & -0.03 & 0.03 \\
\hline$L_{P y}$ & $\mathrm{~m}$ & -0.015 & 0.055 \\
\hline$L_{D x}$ & pixel & 0 & 1024 \\
\hline$L_{D y}$ & pixel & 0 & 780 \\
\hline
\end{tabular}

次に塗り始めの判断について述べる . 上記の通り，ストレスにより不随意運動か強くなりすぎることを避ける ため, 塗り始めの動作は研究者から指定せず被験者のイメージに委ねた .この実験中の被験者の操作動作を観察 し計測データを確認したところ,「はい」と発言したときの動作は実際に筆でキャンバスに絵の具を塗る動作のよ うに，キャンバスに対し鉛直方向に沿って筆を近づける動作を行なっていた．この「はい」と発言したときの動 作を「塗り始め動作」とした .この結果を考慮し $\mathrm{z}$ 軸における挙動に着目し，塗り始め動作と不随意運動を判別 するために $\mathrm{z}$ 軸座標の変化と合成速度の変化との関係を調査した . 一連の操作動作から抜粋した塗り始め動作の 挙動を図 9 に示し，不随意運動の挙動を図 10 に示す。 

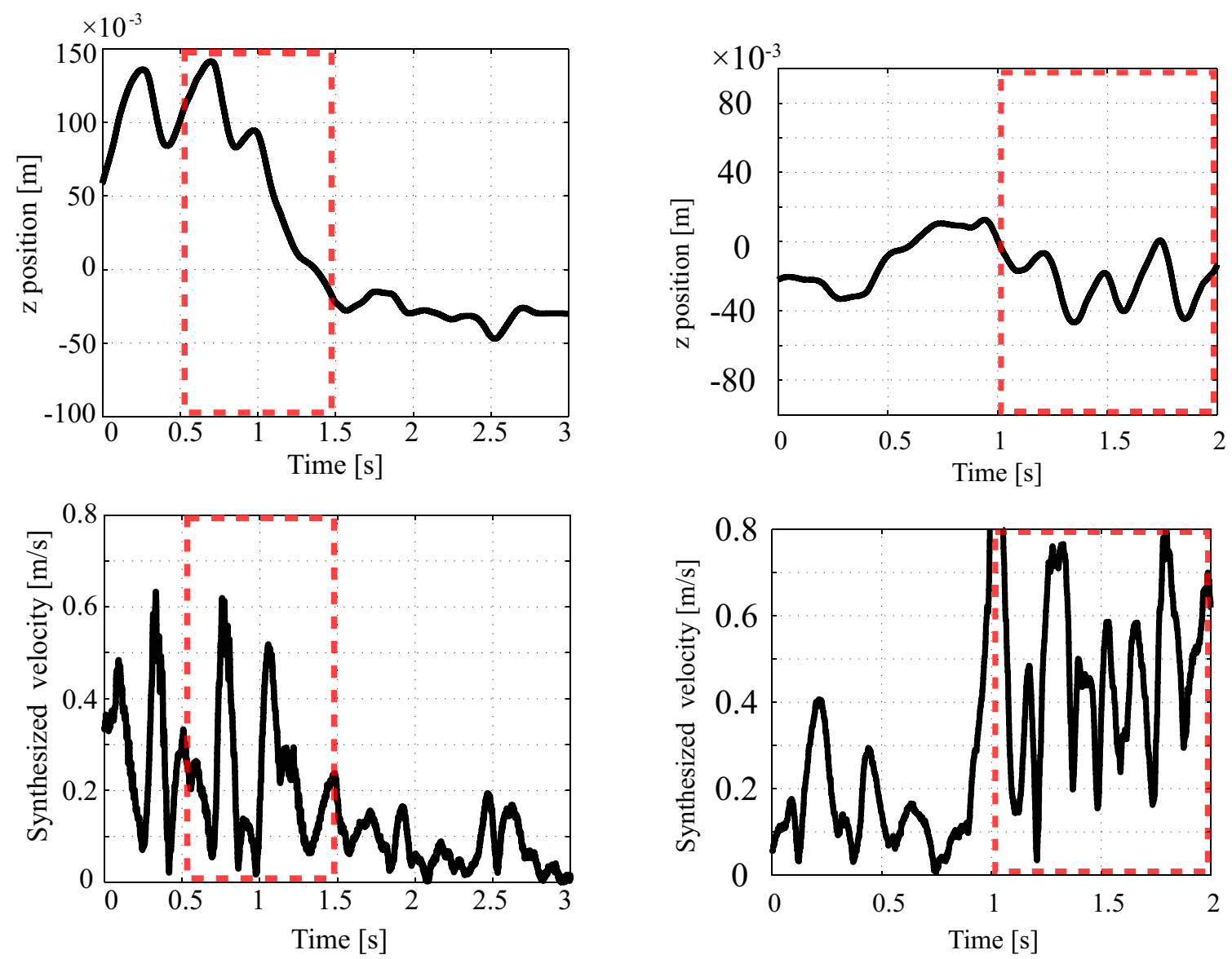

Fig. 9 Behavior of $\mathrm{z}$ position and velocity component during drawing action

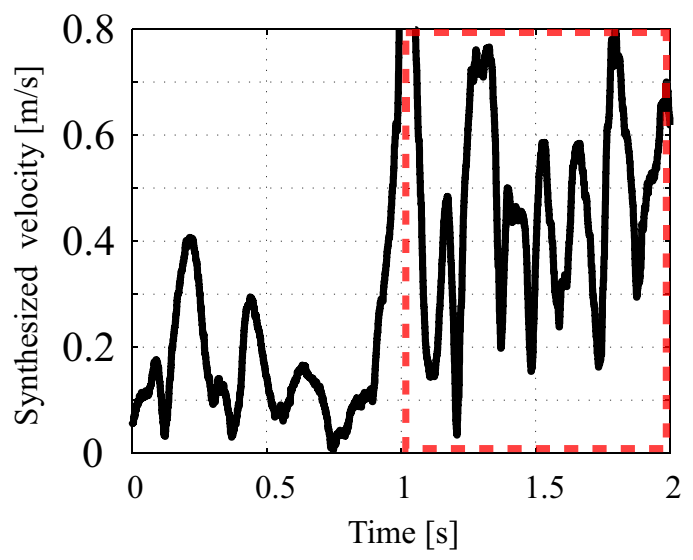

Fig. 10 Behavior of $\mathrm{z}$ position and velocity component during involuntary action

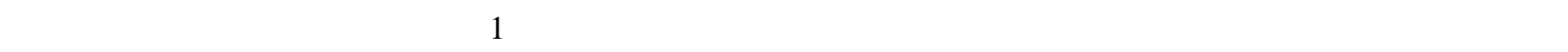
随意運動共に合成速度のピークは $0.5[\mathrm{~m} / \mathrm{s}]$ 前後であり, 合成速度による判別は困難であるが, $\mathrm{z}$ 軸方向の変化で差 異がみられた . 塗り始め動作である図 9 に関して，色つき破線枠で示された 0.5 1.5[s] の区間において , $\mathrm{z}$ 座標 の大幅な降下を確認することができる．不随意運動である図 10 に関して，同じ条件の区間における $\mathrm{z}$ 軸座標の変 化は, 塗り始め動作と比較すると降下時間が短く降下量も小さい . 図 10 の $\mathrm{z}$ 軸座標変化から，極大值と極小值の $\mathrm{z}$ 軸座標の差は大きくとも50[mm] 未満であることが分かる .このことに加え , 描画判定のための落差を大きく設 定しすぎると自然な動作とならず身体的負担を与えてしまうため，塗り始め条件は式 (5) に示すように現時刻と 0.5 秒前の $\mathrm{z}$ 軸座標の差が $50[\mathrm{~mm}]$ 以上となったときと設定した .この塗り始め条件下において被験者が問題なく 操作できることを確認できた .

$$
\Delta z=|z(t)-z(t-0.5)| \geq 50
$$

\section{2 描画支援実験}

本システムを用いて実際に被験者に絵を描いてもらつた . 作品はスタンピングという絵画技法により描く花の 絵である . スタンピングとはスポンジや布の塊など樣々なものでキャンバスを吅くように色付けする技法である． ペイントソフトは, 水彩画のタッチで描画が可能であるフリーソフトウェア「落とし水」 ${ }^{(11)}$ を利用した .このぺ イントソフトでは入力の時間の長さと強さにより色に濃淡をつけることが可能である . 葉の部分は被験者が普段 通りにベクター形式のドローツールを用いて描き，花びらの部分を本システムを用いたスタンピングにて描いた .

作品を描いている最中の 10 秒間における入力信号の挙動を，可変型フィルタを用いない場合に関して図 11 に， 可変型フィルタを用いた場合に関して図 12 に示す.可変型フィルタを用いない場合におけるポインタの挙動は, 動 作方向と移動距離が不規則かつ方向転換が高頻繁であり，意図する位置に留められていないことが明らかである． 


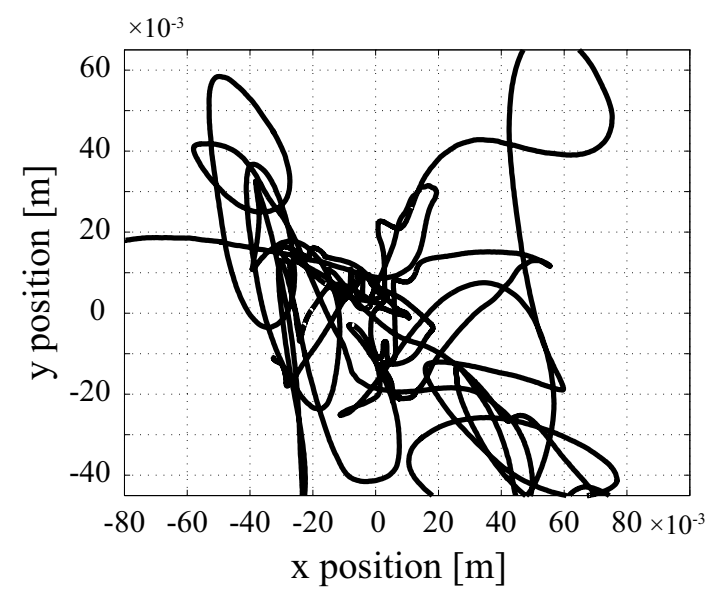

Fig. 11 Original signal for the drawing "Flowers"

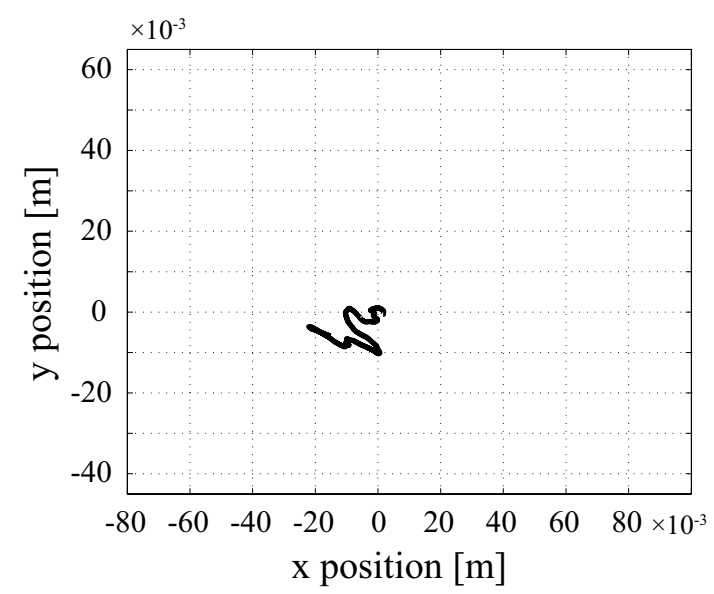

Fig. 12 Filtering signal for the drawing "Flowers"

最終的に可変型フィルタを用いずに描画した作品を図 13 に，可変型フィルタを用いて描画した作品を図 14 に 示す．

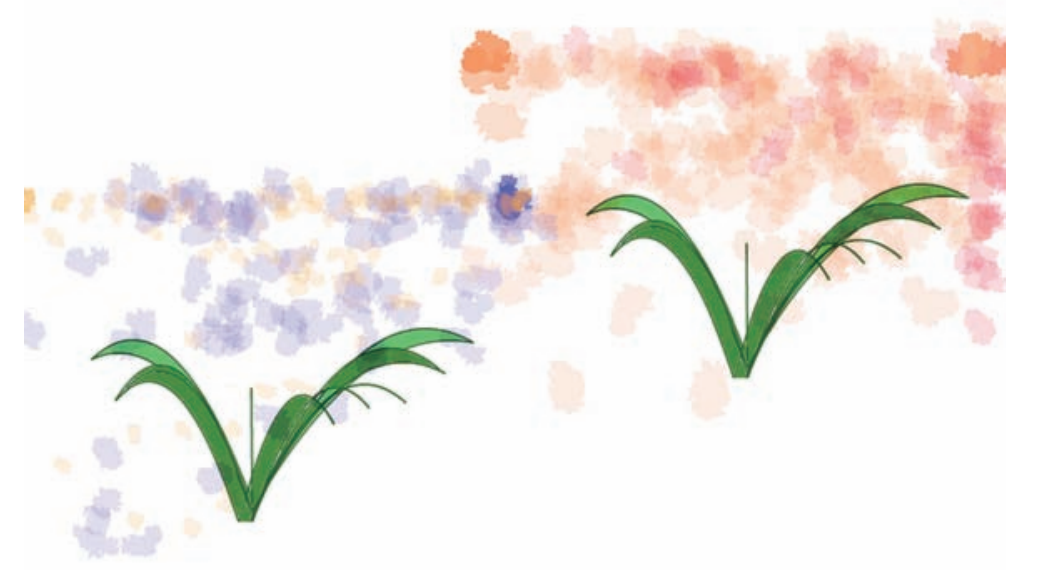

Fig. 13 " Flowers" drawn by the participant (original signal)
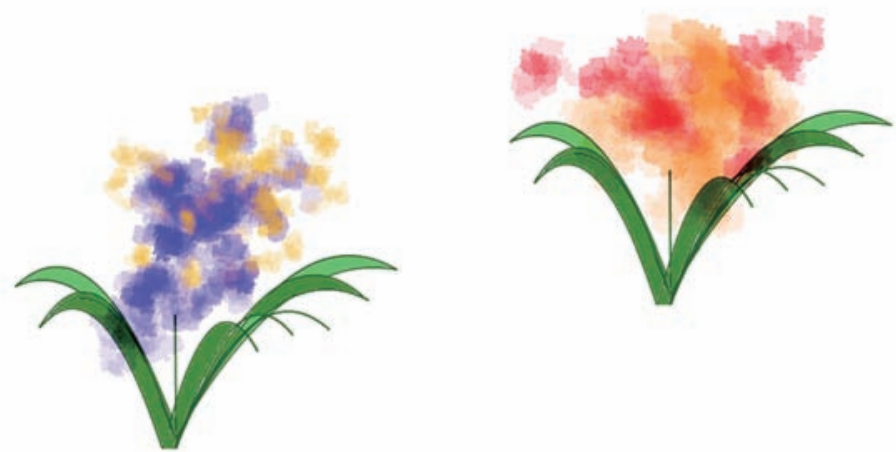

Fig. 14 "Flowers" drawn by the participant (with filtering) 
可変型フィルタを用いない場合では描画位置がキャンバス全体に離散しているが, 可変型フィルタを用いた場 合は描画位置が自然な領域に安定し，被験者の意図する位置近傍への操作が可能になったことがわかる . 結果と して，簡単な色つけではあるが，本システムにより利用者自身の感覚にもとづき，描画することが可能となった 被験者の強弱があり方向および移動距離が不規則かつ複雑であるという特徵はアテトーゼ型脳性麻痺患者の代 表的な症例であることから，式 (2) および式 (3) である可変型フィルタの移動平均法による減衰性能と合成速度に より減衰度を変化させるという機能はアテトーセ型の不随意運動に対して効果的であると考えられる．また，移 動平均時間 $N$ と式 (5) の描き始め条件の設計は, 使用者個々の不随意運動の特徵や使いやすさに合わせて調整可 能である .

最後に，継続的実験を通じて被験者から本描画支援システムに対して感想を得ることができた . 被験者のコメ ントとして，「もっと描きたい」「あの装置おもしろいですよ!!! なにしろ手描きですから，絵を描いているという 実感があります、私は使いたいと思っています」「描画のひとつとして，希望をもちました」というように，本描 画支援システムを気に入っていただき，手で描いているような直感的に使用することができたと感じていた．

6. お り に

本研究では, 緊張性アテトーゼ型脳性麻瘏の方を対象とし, 合成速度による可変型フィルタを用いて不随意運 動の影響を減衰させる描画支援システムを開発した . 開発した可変型フィルタは, 動作方向と移動距離が不規則 かつ方向転換が頻繁に発生する不随意運動の影響を良好に減衰した。緊張性アテトーセ型脳性麻瘒者による描画 支援実験により，本システムの直感的操作性を確認した．

謝 辞

本研究の一部は, 地域イノベーションクラスタープログラム (都市エリア型/岐阜県南部エリア) の助成により 行われた 、ここに記して感謝を表す．

文献

(1) 口と足で描く芸術家協会, http://www.mfpa.co.jp/,(参照日 2010 年 1 月 20 日) .

(2) J. L. Levine, M. A. Schappert, ”A mouse adapter for people with hand tremor”, IBM SYSTEMS JOURNAL , (2005), pp623-624

（3）森本大資, 縄手雅彦, 渡辺哲也, 阿部あかね, 福間慎治, 本多茂男, ”運動障害を持つ人のための手う氿補正機能つきぺ イントツール”，電子情報通信学会 信学技報, (2004), pp59-64

（4）白石 路雄，川瀬穂高，新谷幹夫，“移動平均法を用いた手書きイラストの手っ゙゙れ補正機能”，映像情報メディア学会技術報 告, Vol.34, No.18, (2010), pp23-26

(5) 梶龍兒，不随意運動の診断と治療，(2006), pp72, 診断と治療社, ISBN 4787812971

（6）五味重春, 大津慶子, 鎌倉矩子, 関育子, 君塚葵, 藤原豪, 青山正征, 上田礼子, リハビリテーション医学講座 第 11 巻 脳性麻瘏，(2005), pp32, 医歯薬出版株式会社，ISBN 4263218310

(7) 千野直一, 神経疾患とリハビリテーション, (2005), pp21, 金原出版, ISBN 4307750101

（8）厚生労働省編，平成 18 年身体障害児・者実態調査結果, pp4, 厚生労働省発行

(9) 内閣府編, 平成 19 年度版障害者白書, pp186, 内閣府発行

(10) PHANTOM Omni Haptic Device , http://www.sensable.com/haptic-phantom-omni.htm , (accessed 2010-1-20).

（11）落とし水, http://hp.vector.co.jp/authors/VA029904/otoshimizuex/index.htm，(参照日2 010 年 1 月 20 日). 